\title{
POLA PEMBINAAN KEAGAMAAN NARAPIDANA DI LEMBAGA PEMASYARAKATAN SULAWESI SELATAN
}

\author{
Oleh : H. Pat Badrun
}

\section{PENGANTAR}

Tulisan ini diangkat dari laporan hasil penelitian tentang Pota Pembinaan Kehidupan Beragama Terhadap Narapidana di Berbagai Lembaga Pemasyarakatan di Sulawesi Selatan. Penelitian itu sendiri dilaksanakan oleh Balai Penelitian Lektur Keagamaan Ujungpandang bekerjasama dengan Badan Perencanaan Pembangunan Daerah (BAPPEDA) Tingkat I Sulawesi Selatan dalam tahun anggaran 1994/1995. Sesuai dengan tujuannya maka hasil penelitian telah mengidentifikasikan pola pembinaan kehidupan keagamaan yang dianggap standar serta berlaku pada semua Lembaga Pemasyarakatan yang diteliti, serta aspeknya meliputi materi dan metode pembinaan, sarana dan tujuan serta pencapaiannya, dan hambatan yang dihadapi dalam pelaksanaannya. Laporan hasil penelitian telah dipresentasikan dalam seminar yang diadakan oleh BAPPEDA Tingkat I Sulawesi Selatan dan disampaikan oleh Pat. Baclrun (penulis naskah ini).

\section{PENDAHULUAN}

Lembaga Pemasyarakatan, sebagai institusi sosial, pada dasarnya sudah ada sejak terbentuknya suatu masyarakat dan berkembang seiring dengan perkembangan masyarakat bersangkutan. Demikian pula halnya di Indonesia, institusi ini telah ada jauh sebelum Negara Republik Indonesia Diproklamirkan.

Istilah Lembaga Pemasyarakatan itu sendiri, baru dikenal secara resmi di Indonesia pada tahun 1964", sedang sebelum itu digunakan istilah Rumah Penjara. Perubahan nama isntitusi dari Rumah Penjara menjadi Lembaga Pemasyarakatan merupakan konsekuensi logis dari perubahan sistem pembinaan narapidana sesuai dengan tuntutan perkembangan masyarakat.

Dalam rangka penerapan secara operasional upaya pembinaan narapidana dengan fungsi pemasyarakatan yang terbuka, seluruh pihak yang terlibat dalam proses pembinaan narapidana, telah dibekali dengan prinsip-prinsip dasar pemikiran pembinaan yang berpatokan pada
SEPULVH PRINSIP PEMASYARAKAT$A N$. Bagi petugas dan/atau pembina dibekali dengan kode prilaku yang dirumuskan dalam bentuk "ETOS KERJA", sedang bagi narapidana sendiri dibekali dengan kode perilaku yang dirumuskan dalam bentuk "CATUR DHARMA NARAPIDANA"^. Namun demikian, masyarakat luas belum memiliki informasi yang jelas, bagaimana pola dan betltuk-bentuk kegiatan pembinaan, baik pembinaan mentalspritual/keagamaan maupun pembinaan keterampilan yang diterapkan dan di kembangkan oleh Lembaga Pemasyarakatan, khususnya di daerah Sulawesi Selatan. Tampaknya pihak Lembaga Pemasyarakatan selama ini belum banyak mengekspos sistem pembinaan yang diterapkan terhadap narapidana yang dibina, termasuk di Lembaga Pemasyarakatan yang ada di Sulawesi Selatan.

Upaya pengembangan informasi yang jelas dan benar tentang pola dan bentuk bentuk kegiatan pembinaan narapidana di Lembaga Pemasyarakatan perlu digalakkan demi memperbaiki citra institusi ini dalam persepsi masyarakat sehingga masyarakat 
akan terangsang memberikan partisipasi aktif dan konstruktif dalam rangka pembinaan narapidana, terutama pembinaan para eks narapidana bila kelak mereka kembali ke dalam kehidupan masyarakat luas. Salah satu upaya yang dapat dipandang cukup strategis dalam rangka penyebarluasan informasi tentang pembinaan narapidana dengan sistem pemasyarakatan ialah mengadakan penelitian, sebagaimana halnya penelitian yang hasilnya diangkat dalam tulisan ini.

\section{n. SISTDVf PEMBINAAN NARAPIDANA}

Sistem pembinaan narapidana di LP, secara garis besarnya mencakup aspek atau komponen sarana fisik/material, struktur kelembagaan serta ketentuan-ketentuan yang mengaturnya, dan bentuk-bentuk kegiatan pembinaan.

\section{A. Keadaan Fisik LP yang Diteliti}

Enam LP yang diteliti, sebagai institusi, telah ada sebelum Negara Republik Indonesia Diproklamirkan, namun lokasi dan bangunan masing-masing telah mengalami perubahan, disesuaikan dengan perkembangan masyarakat dan kebutuhan pembinaan narapidana dengan sistem pemasyarakatan.

Letak lokasi bangunan LP yang sebelum penerapan sistem pemasyarakatan berbeda di pusat kota yang justru menjadi nama sebutan masing-masing LP bersangkutan, kemudian dipindahkan ke luar kota atau ke pinggiran kota yang jarak masingmasing LP dengan pusat kota berkisar antara dua kilometer (jarak terdekat sampai 13 kilometer (jarak terjauh).

Bangunan gedung dan komplek LP juga mengalami perubahan site plan (penataan), bentuk, ruangan, keragaman fungsi, dan kapasitas tampung, disesuikan dengan kebutuhan pembinaan. Pada setiap LP yang diteliti, setidaknya memiliki bangunan/ruang : tempat perkantoran, tempat penampungan narapidana/anak didik/tahanan, tempat pendidikan atau ruang belajar, bengkel kerja, aula, poliklinik, rumah ibadah, lapangan olah raga, dan lain-lain.

\section{B. Struktur Kelembagaan dan Pensonalia LP}

Struktur kelembagaan LP sebagaimana diatur dalam Surat Keputusan Menteri Kehakiman RI Nomor 0.1-PR.07.03-1985, mencerminkan antisipasi kelembagaan sistem pemasyarakatan. Hal itu terungkap jelas dengan adanya bagian khusus dalam struktur organisasi LP yang menangani tugas bimbingan dan pembinaan, yakni Seksi Bimbingan Narapidana/Anak Didik dan Kegiatan Kerja. Bagian ini dijabarkan lebih lanjut menjadi tiga bagian lebih kecil atau sub seksi, masing-masing : (1) Sub Seksi Registrasi dan Bimbingan Pemasyarakatan, (2) Sub Seksi Perawatan Narapidana/Anak Didik, dan (3) Sub Seksi Kegiatan Kerja.

Struktur kelembagaan LP tersebut, sekaligus mengandung implikasi penyediaan tenaga/personil kelembagaan yang dibutuhkan untuk mengantisipasi penerapan pembinaan narapidana dengan sistem pemasyarakatan. Pada setiap LP yang diteliti, tersedia personil yang relatif cukup jumlahnya untuk melaksanakan tugas pembinaan, walaupun pada umumnya masih berhadapan dengan masalah profesionalisme yang relevan dengan kebutuhan pembinaan.

Dengan kelengkapan sarana dan fasilitas yang dimiliki, baik fisik-material maupun struktur kelembagaan dan personalia, LP-LP yang diteliti tidak sekedar menampung narapidana yang dipertanggungjawabkan, tetapi juga merewat dan 
POLA PEMBINAAN KEAGAMAAN NARAPIDANA

DI LEMBAGA PEMASYARAKATAN SULAWESI SELATAN

\begin{abstract}
membina mereka serta memperalakukan mereka sebagai subyek, sebagai manusia pribadi dan warga negara yang memiliki hak dan kewajiban sama dengan warga negara lainnya, disamping kewajiban yang berkaitan dengan status mereka selaku narapidana.
\end{abstract}

C. Keadaan Narapidana

Narapidana/tahanan yang ditempatkan pada enam yang diteliti, menurut keadaan pada hari terakhir kunjungan penelitian ke LP lokasi penelitian masingmasing, berjumlah 1.625 orang, terdiri dari 1.336 orang status narapidana, dan 289 orang tahanan. LP yang terbanyak penghuninya ialah LP Kelas I Ujungpandang dengan jumlah 647 orang, dan yang terkurang ialah LP Kelas II B Polewali dengan jumlah 143 orang.

Rincian lebih lanjut mengenai keagamaan narapidana/tahanan di LP-LP yang diteliti, dapat diamati pada Tabel 1 di bawah ini : 
POLA PEMBINAAN KEAGAMAAN NARAPIDANA

DI LEMBAGA PEMASYARAKATAN SULAWESI SELATAN

Tabel 1 : DAFTAR KEADAAN NARAPIDANA DI LP-LP YANG DITELITI DIRINCI MENURUT JENIS KEJAHATAN YANG DILAKUKAN BULAN AGUSTUS ", , SEPTEMBER ${ }^{(2)}$ OKTOBER ${ }^{(3)} 1994$

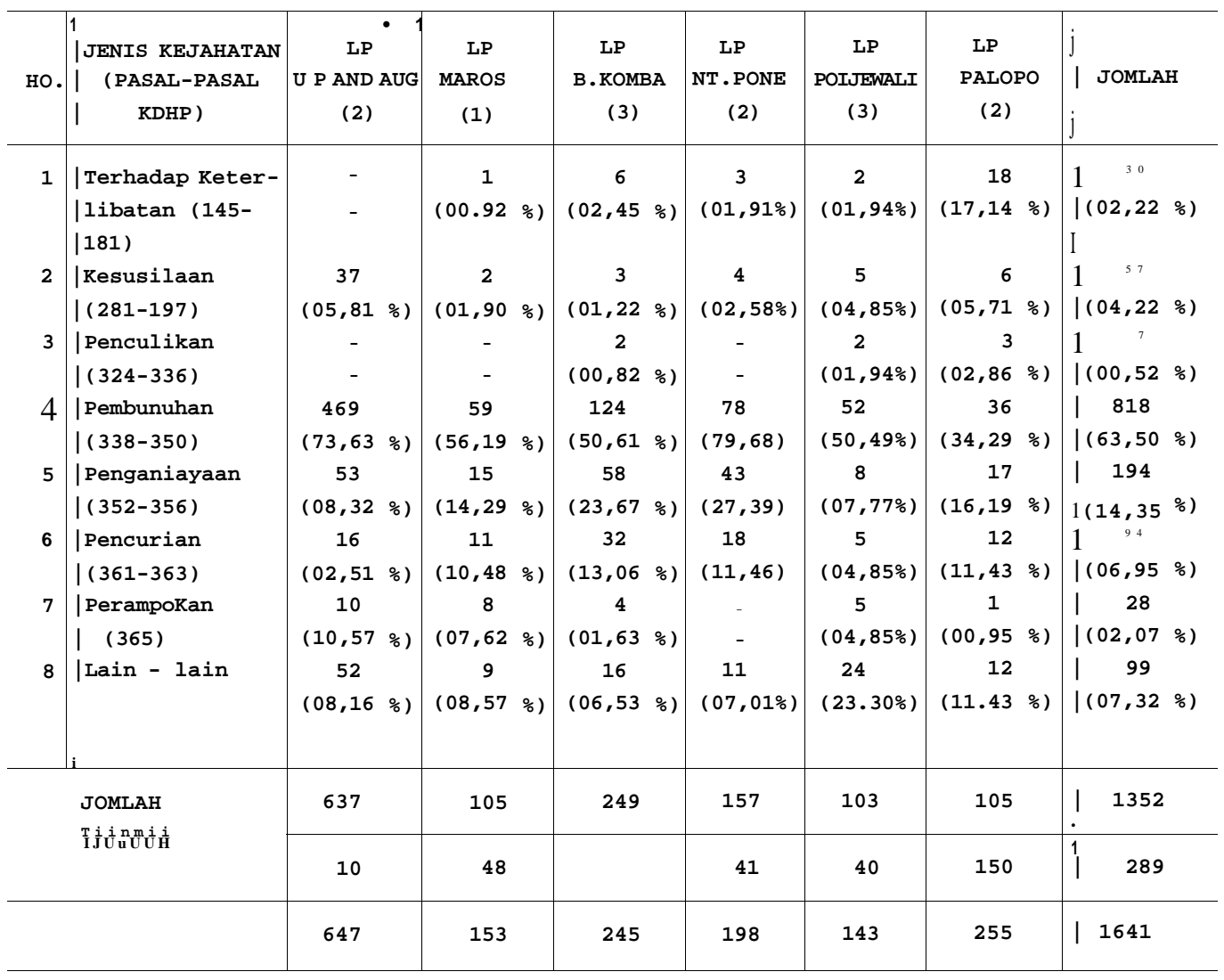

SUMBER : REKAPITULASI TABEL HASIL PENELITIAN MASING-MASING LP.

\section{Wujud Pembinaan Narapidana}

Wujud konkrit dari upaya pembinaan terhadap narapidana yang dilakukan di LP-LP yang diteliti selama ini, antara lain meliputi kegiatan-kegiatan sebagai berikut:

1. Pendidikan Umum, yang ditekankan pada pemberantasan tiga buta (buta aksara, buta angka, dan buta bahasa) melalui pelajaran Kelompok Belajar (Kejar) Paket A dan dilanjutkan dengan pelajaran Kejar Paket B.
2. Pendidikan keterampilan melalui keterampilan membuat barang-barang anyaman, pertukangan kayu, pertukangan loga, mengerjakan bangunan gedung, otomotif, elektronik, jahitmenjahit, dan pertanian.

3. Pembinaan mental spiritual meliputi pendidikan agama termasuk praktek pengamalan ibadah, pendidikan budi pekerti, dan Penataran P4. 
POLA PEMBINA AN KEAGAMAAN NARAPIDANA

DI LEMBAGA PEMASYARAKATAN SULAWESI SELATAN

4. Bimbingan sosial budaya yang menurut program LP dilakukan antara Iain melalui kegiatan kunjungan keluarga ke LP dan pendidikan/latihan kesenian.

5. Kegiatan rekreasi yang sementara difokuskan pada pemupukan kesegaran jasmani dan rohani melalui olahraga, hiburan segar (antara lain menonton film dan/atau televisi), membaca bukubuku dan majalah serta surat kabar yang semuanya dilakukan di dalam LP.

6. Bimbingan koperasi dengan antara lain mengikutsertakan para narapidana dalam koperasi karyawan LP sebagai anggota tidak tetap.

\section{POLA PEMBINAAN KEHIDUPAN KEAGAMAAN NARAPIDANA}

\section{A. Pembinaan Keagamaan Secara Vmum}

Salah satu ciri pokok dari pembinaan narapidana dengan sistem pemasyarakatan ialah pembinaan dibidang mental keagamaan yang semakin diintensifkan pelaksanaannya. Melalui pembinaan dibidang mental keagamaan diharapkan LP dapat berperan aktif dalam mempersiapkan narapidana, baik selama di dalam LP maupun setelah kembali ke masyarakat, untuk memiliki kembali perasaan harga diri yang utuh penuh optimis memandang masa depannya dengan prospek yang cerah serta dengan kesiapan menjadikan hidupnya atau sisa hidupnya lebih bermanfaat untuk diri sendiri, keluarga, masyarakat, dan bangsa. Agama memang menuntun dan membimbing umatnya untuk menjadi manusia yang bermanfaat.

LP-LP yang diteliti, dalam upaya membina narapidana yang dipertanggungjawabkan selama ini sangat memprihatinkan upaya pembinaan dibidang keagamaan dengan perlakuan yang sama terhadap semua pemeluk agama yang dibinanya. Namun demikian, program pembinaan keagamaan di kalangan narapidana yang beragama Islam, tampak lebih bervariasi dengan frekuensi kegiatan yang lebih tinggi dibandingkan dengan program pembinaan keagamaan bagi narapidana pemeluk agama lain. Bahkan ada LP yang pada saat penelitian dilaksanakan, tidak memprogramkan pembinaan keagamaan bagi kalangan narapidana yang beragama lain dari agama Islam. Hal ini antara lain disebabkan :

(1) Aktivitas keagamaan narapidana beragama Islam memang lebih bervariasi, baik ragam kegiatan maupun frekuensinya;

(2) Narapidana penganut agama Islam di LP-LP yang diteliti selama ini selalu mayoritas jumlahnya, sementera narapidana yang beragama lain sangat kurang jumlahnya; bahkan pada tiga LP yang diteliti, saat penelitian berlangsung, hanya dihuni oleh narapidana yang beragama Islam; "

(3) Tenaga pembimbing/pengajar bagi narapidana beragama Islam tersedia cukup, baik dari luar LP maupun orang dalam LP sendiri, sedang pengajar bagi narapidana beragama lain sangat terbatas'

(4) Jumlah jam pelajaran agama, bagi narapidana beragama Islam, 3 jam perminggu dengan frekuensi kegiatan 2 kali perminggu, sedang bagi narapidana beragama lain hanya $1,5 \mathrm{jam}$ perminggu dengan frekuensi kegiatan hanya sekali setiap minggu ${ }^{2}$.

Adapun bentuk-bentuk kegiatan pembinaan keagamaan bagi kalangan narapidana beragama Islam yang dilaksanakan 
POLA PEMBINAAN KEAGAMAAN NARAPIDANA

DI LEMBAGA PEMASYARAKATAN SULAWESI SELATAN

di LP-LP sasaran penelitian selama ini adalah sebagai berikut.

\section{B. Pembinaan Keagamaan Narapidana Beragama Islam}

\section{Penyuluhan Agama}

Dimaksudkan dengan penyuluhan agama disini ialah kegiatan pembi naan/pendidikan agama Islam kepada narapidana yang disampaikan (oleh pembina/pendidik) secara ceramah pidato. Aplikasinya secara operasional, tidak selau sama pada setiap LP yang diteliti. Bahkan pada LP yang sama sering terjadi aplikasi metode penyampaian yang berbeda antara seorang pembina/penceramah dengan penceramah lain.

Ada penceramah yang penyampaiannya lebih bersifat monoton dan one wey traffic (menjurus ke satu arah) tanpa diakhiri dengan diskusi atau tanya-jawab, sementara penceramah lain juga melakukan cara yang sama namun diakhiri dengan diskusi terbatas, karena keterbatasan waktu. Di samping itu, ada pula penceramah yang lebih memberi tekanan pada aspek diskusi, sedang ceramah hanya bersifat mendorong atau merangsang audiens untuk turut berpartisipasi aktif dalam acara diskusi yang waktunya dipersiapkan lebih lama daripada waktu ceramah itu sendiri ${ }^{3}$.

Materi penyuluhan agama pada umumnya tidak diprogramkan secara sistimatik, lebih banyak tergantung pada pilihan penceramah. Namun secara umum dapat dikatakan bahwa materi penyluhan menyangkut semua aspek ajaran Islam, yang meliputi : aqidah, ibadah, muamalah, dan akhlak. Waktu pelaksanaan penyuluhan pada umumnya pada hari Senin dan hari Kamis pada setiap jam 08.00 sampai jam 09.30 waktu setempat.

Penentuan tema materi penyuluhan pada umumnya tidak konsisten (karena tidak terprogramkan) : Hal ini, disebabkan antara lain :

(1) Kesiapan penceramah; kalau diakan penggantian penceramah dilakukan pula perubahan tema;

(2) Permintaan peserta atau narapidana yang menginginkan tema tertentu yang lain dari tema yang telah dirancang semula;

(3) Perubahan tema oleh penceramah sendiri karena adanya pertimbangan tertentu.

Dari pihak penceramah menganggap metode yang diterapkan masing-masing merupakan pilihan terbaik, namun dari pihak narapidana diperoleh kesan yang berbeda-beda. Tetapi pada umumnya narapidana yang diwawancarai pada setiap LP yang diteliti cenderung lebih menyenangi metode yang menitikberatkan pada aspek diskusi secara persuasif dan dengan pilihan tema yang dikompromikan sebelumnya antara penceramah dan narapidana ${ }^{4}$.

\section{Pendidikan Agama}

Dimaksudkan membaca huruf Alquran, dalam pelaksanaannya, peserta dibagi menjadi dua atau tiga kelompok, atas pertimbangan kemampuan baca masingmasing. Untuk pembagian dua kelompok, kelompok pertama terdiri dari narapidana yang sama sekali buta aksara Alquran, sedang kelompok kedua terdiri dari narapidana yang telah mengenal huruf-huruf hijaiyah serta telah memiliki sedikit pengetahuan baca Alquran. Kelompok ketiga (bagi yang mengelompokkan peserta menjadi tiga kelompok), terdiri dari " narapidana yang ingin lebih memperlancar bacaannya serta ingin mengetahui ilmu baca (ilmu tajwid) serta ilmu melagukan bacaan Alquran ${ }^{51}$. 
Penyeleksian tentang potensi dasar membaca Alquran terhadap narapidana dilakukan pada saat narapidana mulai diterima selalu penghuni LP bersangkutan.

Metode yang digunakan masih cenderung lebih banyak kepada Metode Bagdady walaupun metode Iqra' juga telah diperkenalkan. Guru yang mengajar pada tingkat dasar (kelompok pertama dan kedua) pada umumnya orang dalam LP bersangkutan, baik dari karyawan LP maupun dari kalangan penghuni LP sendiri (pada umumnya dari kalangan status tahanan yang dipandang memiliki kemampuan).

Tiap kelompok mendapat giliran satu atau dua kali seminggu secara bergantian, karena hanya menggunakan satu tempat yakni dalam ruangan masjid LP. Waktu belajar pada umumnya sama dengan waktu acara penyuluhan yakni pada setiap jam 08.00 sampai 09.30 (1.5 jam). Peserta terdiri dari narapidana dan tahanan yang pada umumnya pria; bila terdapat peserta wanita, pelajaran dilaksanaka di tempat tersendiri, dan dengan program tersendiri.

Mengenai pendidikan ajaran agama Islam, dimaksudkan ialah pelajaran tentang aspek-aspek ajaran Islam yang pelaksanaannya diberikan secara terprogramkan baik materi maupun silabusnya. Buku pedoman pengajar bermacam-macam; ada yang menggunakan buku pegangan guru agama di Sekolah Lanjutan (umum) Tingkat Pertama dan Tingkat Atas ada pula yang menggunakan buku lain, seperti Buku Fiqhus Sunnah karangan H. Sulaeman Rasyid dan Buku Fiqhi Wadhi karangan Prof. Dr. Mahmud Yunus; (untuk mata pelajaran fiqhi : ibadah dan muamalah); Buku Mukhtarul Hadits untuk mata pelajaran akhlak; Buku Terjemahan Alquran Departemen Agama untuk mata pelajran Tafsir Alquran, disamping buku- buku lain yang relevan sesuai pilihan guru atau pembina. Bahkan ada pengajar yang tidak menetapkan buku tertentu sebagai buku pegangan, melainkan meramu sendiri sesuai pengetahuan dan wawasannya.

Tempat belajar dipilih tempat/ruangan yang dapat diidentifikasi sebagai tempat belajar secara klasikal. Di tempat yang sama juga dilaksanakan pelajaran Kejar Paket A dan Kejar Paket B.

Para peserta dibagi atas kelompokkelompok, pada umumnya terdiri dari 40 orang setiap kelompok. Pembagian peserta atas beberapa ruang belajar serta efektivitas pelaksanaan proses belajar mengajar. Pada umumnya setiap kelompok mendapat giliran belajar sekali setiap dua minggu, karena tatap muka pelajaran ini diberikan dua kali seminggu.

\section{Ibadah Bersama}

Dimaksudkan dengan ibadah bersama disini ialah ibadah yang di-lakukan secara bersama-sama (berjamaah), meliputi : Shalat berjamaah (waktu Zuhur dan Ashar), Ibadah Jum'at (Khutbah dan Shalat Jum'at), Ibadah Ramadhan (puasa, tarawih, zakat fitrah), serta Ibadah (Shalat dan Khutbah) pada dua hari raya yakni Hari Raya Idul Fitri dan Idul Adha.

a. Shalat Berjamaah

Shalat berjamaah lima waktu dengan jumlah jamaah yang banyak serta dilaksanakan di masjid LP hanyalah untuk dua waktu shalat, yakni waktu Zuhur dan Ashar. Untuk waktu shalat lainnya (Magrib, Isya, dan Shubuh) dapat dilakukan secara berjamaah di blok atau kamar masingmasing. Pada bulan Ramadhan sering dikecualikan, yakni shalat berjamaah lima waktu dapat dilakukan di masjid LP. Bagi narapidana wanita mereka dapat shalat berjamaah di blok/kamar mereka. 


\section{POLA PEMBINAAN KEAGAMAAN NARAPIDANA DILEMBAGA PEMASYARAKATAN SULAWESI SELATAN}

Imam shalat berjamaah di masjid LP pada umumnya dari petugas LP, namun terkadang pula diambil dari kalangan narapidana sendiri atas penunjukkan langsung petugas LP/pembina atau atas kesepakatan peserta shalat berjamaah itu sendiri.

\section{b. Ibadah Jum 'at}

Dimaksudkan dengan ibadah Jum'at disini ialah ibadah khusus yang dilaksanakan pada hari Jum'at, yakni Khutbah dan Shalat Jum'at yang dilaksanakan di masjid LP masing-masing.

Peserta ibadah Jum'at terdiri dari para narapidana dan tahanan serta karyawan LP. Acaranya, terutama acara Khutbah Jum'at, terjadwalkan selama satu tahun (menurut kalender Masehi). Pembawa khutbah (Khatib) sebagian besar dari kalangan luar LP, terbanyak dari instansi Departemen Agama setempat. ${ }^{6}$

Dalam hal pelaksanaan ibadah Jum'at, petugas LP yang bertanggungjawab dalam pembinaan keagamaan narapidana di LP-LP yang diteliti, menerapkan kebijaksanaan yang agak tegas terhadap narapidana untuk menghindari acara ibadah Jum'at ini. Setiap narapidana beragama Islam yang tidak berhalangan atau tidak memiliki alasan yang dibenarkan hukum syara' untuk dapat meninggalkan kewajiban ibadah Jum'at, harus mengikutinya. Karena itu pengunjung selalu banyak pada setiap pelaksanaannya, bahkan terkadang tidak tertampung oleh ruangan masjid LP.

Meteri khutbah berkisar pada halhal pokok atau ajar an pokok Islam dan sering dikaitkan dengan fenomena kehidupan sehari-hari yang dianggap akut/hangat serta aktual/nyata, sering pula dikaitkan denga peristiwaperisti wa sejarah yang berhubungan dengan hari/tanggal serta bulan berjalan (bulan Qamariah dan bulan Masehi).

Walaupun acara ibadah Jum'at sudah terjadwalkan (pembawa acaranya) selama satu tahun, namun sering terjadi pembawa acara (terutama acara khutbah) dari luar LP sebagaimana yang telah diprogramkan, tidak/berhalangan hadir tanpa atau dengan penyampaian mendadak. Alternatif yang lazim ditempuh karena kurang "berisiko" ialah menggunakan orang dalam Sendiri yakni petugas LP yang memiliki potensi atau biasa melakukannya, walaupun alternatifa ini lebih bersifat "tidak ada rotan akar pun jadi".

Altenatif yang ditempuh itu, disatu pihak memang dapat mengatasi masalah, namun dilain pihak dapat menimbulkan implikasi negatif dilihat dari sisi fungsi pembinaan keagamaan narapidana. Hal yang dimaksud ialah masalah kualitas pesan/khutbah serta maslah hubungan khatib (yang notabene petugas LP) dan jamaah (narapidana). Yang dimaksud terakhir, cenderung bersifat hubungan "penjaga" dan yang "dijaga" sehingga dapat menimbulkan kesan berupa jera/tekanan psikologis serta kejenuhan di kalangan jamaah selaku narapidana. Kedua hal, sangat mempengaruhi dalam arti menghambat proses penerimaan pesan khutbah bagi Jcalangan narapidana bersangkutan.

\section{c. Ibdah Ramadhan}

Berbagai aktivitas keagamaan yang dilakukan umat Islam berkaitan dengan kedatangan bulan Ramadhan yang dimaksudkan untuk memberikan makna penting kepada keutamaan bulan ini, juga dilakukan oleh penghuni LP-LP yang diteliti selama ini. Ibadah puasa di siang hari, dalam arti tidak makan dan tidak minum di siang hari, selama 
waktu tertentu, diikuti oleh hampir seluruh narapidana/tahanan yang beragama Islam. Ikhlas atau tidak, narapidana muslim harus melaksanakan puasa pada siang hari bulan Ramadhan karena pihak pengelola LP tnenerapkan kebijaksanaan hanya dua kali makan sehari semalan yakni "makan sahur" dan makan malam" saja.

Ibadah khusus pada malam hari bulan Ramadhan, yakni shalat Tarawih, juga tidak ketinggalan dilaksanakan di LP-LP yang diteliti walaupun untuk pelaksanaan acara itu, diperlukan kebijaksanaan pihak penanggung jawab LP dalam hal buka tutup kunci blok penampungan narapidana sampai larut malam. Ceramah-ceramah keagamaan setiap malam menjelang shalat Tarawih, juga selalu diadakan, yang acaranya pada umumnya telah disusun sebelumnya selama satu bulan penuh. Acara tadarrusan yakni membaca Alquran dengan suara nyaring, sangat mewarnai kegiatan keagamaan narapidana bulan Ramadhan, baik di siang hari maupun malam hari (sesudah acara shalat Tarawih), di kamar-kamar secara pribadi ataupun di masjid LP secara kelompok dan bergiliran, dibawah pengawasan petugas LP.

Di beberapa LP, pada bulan Ramadhan diadakan pula kegiatan lomba baca Alquran atau yang lazim dikenal dengan sebutan Musabaqah Tilawatil Quran (MTQ) antar narapidana. Pemenangnya, selain mendapat hadirah berupa uang, benda dan tropi, juga dipersiapkan sebagai peraturan LP bersangkutan mengikuti MTQ antar LP yang selama ini dilaksanakan di LP Kelas 1 Ujungpandang.

Selain kegiatan-kegiatan tersebut, para narapidana muslim tidak pula ketinggalan membayar zakat fitrah, terutama pada hari-hari terakhir atau minggu terakhir bulan Ramadhan.
Zakat fitrah mereka diterimakan melalui petugas LP yang khusus menanganinya untuk kemudian diserahkan lebih lanjut kepada pihak yang berhak menerimanya.

Pendek kata, dalaffl bulan Ramadhan, kegiatan keagamaan tampak mehdominasi suasana kehidupan di LP-LP yang diteliti, tentu saja karena adanya dukungan kebijaksanaan dan kearifan dari pihak pengelola LP masingmasing.

d. Ibadah Plan Raya ldul Fitri dan Idul Adha

Kegiatan yang dilakukan umat Islam di luar LP berkaitan dengan Hari Raya Idul Fitri dan Idul Adha selalu diupayakafl pula untuk dilaksanakan di LP-LP yang diteliti, sekalipun dalam serta keterbatasan sesuai dengan situasi dan kondisi serta ketentuan yang berlaku di LP bersangkutan.

Adapun kegiatan-kegiatan keagamaan yang dilakukan itu antara lain, acara takbiran menjelang malam serta pada malam hari raya bersangkutan, pelaksanaan shalat dan khutbah hari raya bersangkutan, ramah-tamah dan silaturahmi antar penghuni LP serta antara penghuni LP dengan sanak keluarga yang berkunjung ke LP.

Menjelang tibanya Hari Raya idul Fitri, dilakukan pembayaran/penyetoran dan pembagian zakat fitrah dari karyawan dan narapidana kepada narapidana dan fakir miskin di sekitar lokasi LP, di bawah koordinasi petugas LP. Khusus pada Hari Raya Idul Adha, dilakukan penyembelihan hewan qurban bagi yang mampu, baik di kalangan pengelola LP maupun dari kalangan narapidana, serta membagibagikan daging hewan qurban tersebut di dalam LP sendiri melalui dapUr umum. 
Pembawa acara pokok pada perayaan kedua hari raya tersebut, pada umumnya didatangkan dari luar LP yakni dari instansi mitra kerja dan/atau perorangan yang memiliki kompetensi (ustadz, ulama, kiyai) atau yang telah dikenal "populer".

\section{Praktek Ibadah}

Yang dimaksud dengan praktek ibadah disini ialah bimbingan kepada narapidana untuk mepraktekkan tata cara atai kaifiat pelaksanaan ibadah serta bentuk-bentuk kegiatan yang menyertainya, seperti shalat, wudhu, tayammum, istinta, dan bentuk-bentuk ibadah lainnya, termasuk bacaanbacaan dalam ibadah tersebut.

Acara inii biasanya dilaksanakan setelah selesai shalat berjamaah waktu Dzuhur dan/atau shalat Jum'at, atau sering pula diprogramkan sebagai salah satu materi yang disampaikan dalam acara pendidikan agama.

Maksud acara ini ialah untuk mengecek ketepatan pengetahuan narapidana menyangkut tata cara pelakasanaan suatu bentuk ibadah tertentu untuk kemudian menuntun mereka yang masih mempraktekkan tata cara ibadah yang masih mempraktekkan tata cara ibadah yang tidak/ kurang benar menurut ketentuan syara. Ternyata ketika dilakukan pengecekan didapati masih banyak narapidana beragama Islam yang sangat kurang pengetahuan dalam tata cara ibadah shalat, wudhu, tayammum, mandi junub dan istinja. Karena itu maka praktek ibadah ini diprogramkan sebagai salah satu materi kegiatan atau pe'mbinaan keagamaan narapidana di LP-LP yang diteliti.

\section{Peringatan Hari-hari Bersejarah dalam Islam}

Dimaksudkan dengan hari-hari bersejarah dalam Islam disini ialah hari/tanggal yang bertepatan dengan atau berkaitan dengan peristiwa-peristiwa sejarah yang penting dalam sejarah perkembangan Islam pada masa kerasulan Muhammad saw., dan telah dijadikan tradisi memperingatinya di Indonesia. Peristiwa sejarah dimaksud meliputi : kelahiran Nabi Muhammad saw yang lazim dikenal dengan Maulid Nabi Muhammad saw; Isra' Mi'raj Nabi Muhammad saw dan Nuzul Al qur'an. Ketiga peristiwa bersejarah tersebut selalu diperingati pada waktunya di LP-LP yang diteliti, walaupun kehadiran narapidana tidak terlalu di-tuntut sebagai keharusan seperti halnya bila melaksanakan ibadah Jum'at. Namun demikian, hanya narapidana yang berhalangan saja yang tidak menghadiri acara-acara tersebut.

Penceramah pada acara-acara tersebut sebagaimana lazimnya didatangkan dari luar LP, dengan mengupayakan tokoh agama/muballig yang sudah dikenal kepopulerannya di daerah lokasi LP bersangkutan.

Biasa juga dilaksanakan rangkaian acara sebelum pelaksanaan acara inti, seperti mengadakan perlombaan mengumandangkan azan/bang, perlombaan membaca surah-surah pendek dalam Alquran, dan kegiatan-kegiatan lain. Pesertanya, tidak hanya dari kalangan narapidana usia muda, tetapi juga ada dari kalangan dewasa dan orang tua.

Keikutsertaan para narapidana pada acara-acara tersebut banyak tergantung pada dorongan dan motivasi yang diberikan oleh petugas pengelola.

\section{Kegiatan Sosial Keagamaan}




\begin{abstract}
Dimaksudkan dengan kegiatan sosial keagamaan disini ialah santunan sosial untuk narapidana yang meninggal di dalam LP, baik yang pengurusannya dilakukan di dalam LP (tidak ada keluarga yang mengambilnya) maupun yang diurus keluarganya di luar LP. Santunan yang diberikan sebagai pertanda rasa solidaritas dan senasib sepenanggungan selaku warga LP bersangkutan. Bentuk santunan berupa sumbangan uang yang diambilkan dari simpanan/Tabanas setiap narapidana melalui koordinasi petugas, diberikan kepada pihak yang bertanggung jawab mengurus jenazah bersangkutan.
\end{abstract}

Demikianlah bentuk-bentuk kegiatan keagamaan yang dilaksanakan di LP-LP yang diteliti sebagai upaya pembinaan mental keagamaan narapidana dalam rangka penerapan sistem kemasyarakatan. Teknik, variasi, dan frekuensi kegiatan keagamaan antara satu LP dengan LP yang lain, sedikit banyaknya terdapat perbedaan, hal mana sangat ditentukan oleh sarana pendukung serta potensi yang dimiliki masing-masing LP, di samping ditentukan pula oleh keberadaan narapidana itu sendiri selaku sasaran pembinaan. Oleh karena bentuk-bentuk kegiatan keagamaan yang dilaksanakan itu cenderung dibakukan oleh masing-masing LP maka dapatlah dikatakan bentuk-bentuk kegiatan itu merupakan pola pembinaan keagamaan narapidana pada LP bersangku$\tan$.

\section{Persepsi Terhadap Pembinaan Narapi- dana}

Penelitian ini berupaya memperoleh informasi dari pihak-pihak yang terkait dengan upaya dan proses pembinaan narapidana di LP-LP yang diteliti. Informasi yang dimaksudkan berupa tanggapan dan/atau penilaian mereka terhadap pembinaan narapidana dan terhadap faktor-faktor yang dikemukakan di atas. Sebagian.dari tanggapan dan penilaian mereka yang dianggap penting mendapat perhatian, dikemukakan sebagai berikut.

Pengelola, dalam hal ini pembina di LP menilai bahwa upaya penerapan kebijaksanaan pembinaan narapidana dengan sistem pemasyarakatan di LP-LP yang diteliti betapapun telah mencatat berbagai keberhasilan, dalam arti mengacu kepada tujuan pembinaan narapidana itu sendiri sebagaimana dinyatakan di dalam Keputusan Menteri Kehakiman RI Nomor M.02.PK.04.10 Tahun 1990, tanggal 10 April $1990{ }^{\circ}$ Keberhasilan itu dimungkinkan karena adanya faktor-faktor pendukung, baik dalam bentuk fisikmaterial maupun dalam bentuk struktur, sistem, dan personil yang satu dengan lainnya saling mendukung serta menyatu dalam mekanisme kerja yang bersistem (sebagaimana telah dikemukakan pada Bab II).

Namun demikian tidak dapat disangkal adanya hambatan-hambatan yang betapapun keadaannya mempengaruhi kelancaran pelaksanaan pembinaan dan pada akhirnya mempengaruhi pula tingkat pencapaian hasil.

Pihak Departemen Kehakiman sejak dini telah mengidentifikasikan beberapa hal yang pada satu sisi merupakan faktor pendukung namun pada sisi lain dapat menjadi faktor penghambat. Hal-hal yang dimaksud antara lain : beberapa hal yang telah dikemukakan di atas, masalah anggaran, kuantitas dan kualitas tenaga pembina serta kemampuan/keterampilan pengelolaan; ketersediaan sarana/fasilitas pembinaan, ketersediaan sumber daya alam dan lingkungan, serta hal-hal yang berkaitan dengan warga binaan dan persepsi masyarakat.

Hambatan yang sangat dirasakan pihak pengelola LP ialah keterbatasan alokasi 


\section{POLA PEMBINAAN KEAGAMAAN NARAPIDANA \\ DI LEMBAGA PEMASYARAKATAN SULAWESI SELATAN}

dana pembinaan, terutama dalam pembinaan mental keagamaan. Dana yang digunakan selama ini, sering diambil dari dana pembinaan kegiatan lain yang memang juga terbatas, sepanjang dapat dipertanggungj awabkan. Kedengarannya memang ironis, bahwa pembinaan mental alokasi dana untuk itu sangat terbatas, kalau tidak ingin dikatakan nihil.

Hambatan lain ialah kurangnya tenaga pembina, baik di bidang mental keagamaan maupun di bidang kegiatan lain.

Di bidang keterampilan, ada keengganan dari pihak mitra kerja untuk mengembangkan terus kerjasama pembinaan dengan alasan antara lain, kurang efisien karena narapidana yang dibina cenderung kurang memiliki etos kerja yang mendukung, mereka turut dibina hanya karena terpaksa. Selain itu produk yang dihasilkan narapidana lewat bimbingan keterampilan kurang diminati masyarakat umum, karena antara lain, masalah mutu. Juga masih sangat kurang pihak luar yang bersedia menjadi penadah dan penyalur hasil produksi, sehingga banyak produk yang terpaksa "digudangkan". Pada hal bila produk tersebut dapat laku semua maka pengembalian investasi akan lancar dan sebagian dari hasil penjualan dapat disumbangkan ke Kas Negara sebagai partisipasi narapida terhadap pembangunan, dan sebagainya dapat dimanfaatkan oleh narapidana sendiri untuk kebutuhan sehari-hari serta untuk berpartisipasi mengembangkan koperasi karyawan LP dimana mereka juga didaftar sebagai anggota "tidak tetap".

Dari hasil pemantauan petugas LP, diketahui bahwa banyak bekas narapidana yang tidak dapat mengembangkan pengetahuan keterampilan mereka di luar LP karena tidak ada pihak yang bersedia membantu permodalan atau sangat jarang pengusaha yang bersedia mempekerjakan mereka. Akibatnya banyak diantara mereka yang menjual peralatan praktek kerja yang diberikan LP sehingga sulit diharapkan pembangunan usaha mereka.

Rupanya persepsi "buruk" terhadap bekar narapidana yang sering dituding "penjahat" belum sirna di kalangan masyarakat, sehingga bekas narapidana selalu disisihkan dalam pergaulan dan interaksi sosial.

Masalah keterbatasan dana operasional pembinaan kehidupan beragama narapidana di LP juga berdampak pada kesulitan penggunaan tenaga pembina yang berkualitas yang pada umumnya tenaga dari luar LP. Betapapun penggunaan tenaga luar perlu dipersiapkan biaya minimal untuk keperluan transportasi. Namun hal itu sering tak teratasi sehigga terpaksa memanfaatkan tenaga orang dalam LP sendiri yang pada umumnya sekedar "kalau tiak ada rotan akar pun jadi". Keadaan demikian tentu saja menimbulkan masalah "kualitas produk" binaan.

Mengenai bentuk-bentuk kegiatan keagamaan yang dilaksanakan, setiap LP yang diteliti, menganggap hal itu sebagai upaya optimal yang dapat mereka lakukan sesuai kondisi masing-masing LP. Walaupun mereka menyadari kekurangan yang ada sebagai akibat keterbatasan, namun setiap LP telah membakukan bentuk-bentuk kegiatan tersebut sebagai satu pola pembinaan kehidupan keagamaan narapidana yang efektif di LP masing-masing.

Sementara itu dari kalangan narapidana, sistem pembinaan yang diterapkan itu mendapat respon positif dalam wujud kesediaan mereka menerima upaya pembinaan sesuai dengan kondisi dan situasi masing-masing. Mereka memberikan respon positif sebagai manifestasi dari rasa kesyukuran mereka menerima pembinaan yang manusiwi, terutama bagi 
Keberhasilan LP Kelas I Ujungpandang membina keterampilan narapidana dalam industri kerajinan rotan bekerjasama dengan PT. Gimex Co, barangkali dapat dijadikan contoh.

\section{KESIMPULAN}

\section{A. Kesimpulan}

1. Penelitian tentang Pola Pembinaan Kehidupan Keagamaan Terhadap Narapidana di Berbagai Lembaga Pemasyarakatan di Sulawesi Selatan menyimpulkan bahwa penerapan kebijaksanaan pembinaan narapidana dengan sistem pemasyarakatan telah diupayakan oleh masing-masing LP yang diteliti seoptimal mungkin sesuai dengan kondisi, situasi, dan potensi yang dimiliki. Tingkat keberhasilan masing-masing LP sangat ditentukan oleh kemampuan dan kreativitas pengelola LP untuk mengembangkan potensi sumber daya yang dimiliki serta kemampuan memenej dengan baik, partisipasi pihak luar dalam wujud program kegiatan nyata yang mengacu kepada sistem pembinaan dan peningkatan sumber daya manusia. Namun demikian para narapidana pada umumnya menanggapi sistem pembinaan yang mereka terima itu sebagai sangat manusiawi. Melalui pembinaan itu mereka dapat memiliki pengetahuan "dan keterampilan, dapat lebih memahami dan mengamalkan ajaran agama, hal yang mungkin sulit mereka peioleh sekiranya tidak pernah menjadi penghuni LP.

•No. 13 Th. VIII Juli/Desember 1996
2. Pembinaan kehidupan beragama terhadap narapidana di LP yang diteliti, telah diberikan secara intensif dan diprogramkan secara kontinue sebagai salah satu kegiatan pembinaan yang penting. Tampaknya masih terdapat sedikit perbedaan antara satu LP dengan LP lain dalam hal variasi kegiatan, frekuensi dan intensitas, serta teknik-teknik penyelenggaraan. Hal ini antara lain disebabkan karena belum adanya satu pola pembinaan standard yang dapat dijadikan acuan bersama.

3. Bentuk-bentuk kegiatan pembinaan keagamaan yang dilaksanakan di LP yang diteliti secara umum sama atau hampir sama dengan bentuk-bentuk kegiatan keagamaan yang dilaksanakan masyarakat umum di luar LP yakni meliputi :

(1) Penyuluhaan agama, yakni kegiatan bimbingan keagamaan yang lebih bersifat ceramah;

(2) Pendidikan Agama, meliputi pendidikan membaca Alquran dan pendidikan ajaran agama Islam itu sendiri;

(3) Ibadah bersama, meliputi shalat berjamaah (lima waktu sehari semalam), ibadah/shalat Jum'at, ibadah bulan Ramadhan (puasa siang hari, shalat Tarawih malam hari), ceramah agama, tadarrus Al-Qur'an, dan mengeluarkan zakat fitrah), ibadah hari raya Idul Fitri dan Idul Adha;

(4) Praktek Ibadah, yakni bimbingan mempraktekkan tata cara pelaksanaan 
POLA PEMBINAAN KEAGAMAAN NARAPIDANA

DI LEMBAGA PEMASYARAKATAN SULAWESI SELATAN

suatu ibadah khusus serta kegiatan yang menyertainya, seperti ibadah shalat, wudhu dan tayammum, istinja serta bacaan dan doa di dalamnya;

(5) Peringatan hari bersejarah keagamaan, meliputi Maulid Nabi Muhammad saw, dan Nuzul Qur'an

(6) Kegiatan sosial Keagamaan, yakni bimbingan solidaritas serta santunan sosial kepada teman-teman sesama narapidana yang kena musibah serta santunan sosial lainnya.

4. Faktor dana rupanya menjadi faktor penentu dalam upaya setiap LP menerapkan pola pembinaan yang "ideal", terhadap narapidana yang diasuh, terutama pembinaan di bidang keagamaan yang tidak memiliki alokasi dana tersendiri. Keterbatasan dana pengelolaan berdampak pada pelaksanaan kegiatan yang "asal jadi" serta penggunan tenaga pembina yang "kalau tidak ada rotan akarpun jadi". Keadaan demikian menimbulkan konsekuensi masalah kualitas hasil binaan.

\section{B. Saran-saran}

1. Dalam rengka penerapan konsep fungsi pemasyarakatan yang terbuka dan produktif, betapapun LP sangat memerlukan partisipasi pihak luar (instansi pemerintah lainnya, lembaga sosial, badan usaha, dan masyarakat pada umumnya). Karena itu untuk merangsang keinginan dan kegairahan pihak luar berpartisipasi dalam pembinaan narapidana di LP perlu penyebarluasan informasi mengenai program pembinaan narapidana melalui berbagai peluang dan media komunikasi.
2. Mengingat bahwa pembinaan mental keagamaan merupakan bagian penting (atau bahkan terpenting) dari seluruh aspek pembinaan yang diprogramkan terhadap narapida maka seyogianya dana pembinaan keagamaan dialokasikan tersendiri dan kalau dapat diprioritaskan.

3. Untuk mengintensifkan pembinaan keagamaan terhadap narapidana di LP, seyogianya tenaga pembina dari luar ditangani dan/atau dikoordinir langsung oleh instansi Departemen Agama (yang berwenang) setempat, dengan cara antara lain menempatkan tenaga pembina agama secara khusus. Alternatif lain yang dapat ditempuh dalam penerimaan pegawai baru kiranya pihak LP merekrut secara khusus tenaga potensial misalnya tenaga yang berijazah pendidikan agama bahkan kalau dapat yang berijazah sarjana agama.

4. Cara pembinaan kehidupan keagamaan narapidana di LP (setidaknya di Sulawesi Selatan) perlu dibuatkan pola umum yang baku/standar agar memudahkan upaya mengantisipasinya. Pola umum yang standar tersebut rnemuat antara lain petunjuk pelaksanaan, petunjuk teknis, penyusunan program kegaitan, penyiapan sarana pendiikung (termasuk dana), penetapan target dari tujuan, penyusunan sistem monitoring dan evaluasi. Untuk itu disarankan bahwa dalam upaya penyusunan pola pembinaan keagamaan yang baku, kiranya bentuk-bentuk kegiatan keagamaan dirurriuskan pada kesirhpulan nomor 3 di atas, agar dapat dijadikan acuan. 
POLA PEMBINAAN KEAGAMAAN NARAPIDANA

DI LEMBAGA PEMASYARAKATAN SULAWESI SELATAN

5. Upaya pembenahan sistetn pembinaan keagamaan narapidana dalam rangka menemukan pola pembinaan yang diharapkan (idea!) perlu dilakukan secara mendasar dan sistimatis. Salah satu upaya lebih lanjut dengan menerapkan "Action Research" atau Peneleitian Operasional dalam mana diperlukan adanya "pilot projek" atau proyek yang diujicobakan.

\section{CATATAN}

\section{BAB I}

1) Tanggal 27 April 1964, tercapainya kesepakatan antara peserta Rapat Kerja Kepala Jawatan Pemasyarakatan se Indonesia di Bandung, untuk merubah perlakuan terhadap narapidana dari sistem kepenjaraan ke sistem Pemasyarakatan.

2) Departemen Kehakiman RI Pola Pembinaan Narapidana/Tahanan (Jakarta : 1990), Cet. I, hal. 9-22.

\section{BAB II}

1) Surat Keputusan Menteri Kehakiman RI Nomor M.01.PR.07.03 Tahun 1985 tentang Organisasi dan Tata Kerja Lembaga Pemasyarakatan.

\section{BAB III}

1) Keadaan Narapidana di LP-LP yang diteliti menurut pemelukan agama, dapat dilihat pada tabel di bawah : 
POLA PEMBINAAN KEAGAMAAN NARAPIDANA

DI LEMBAGA PEMASYARAKATAN SULAWESI SELATAN

\section{KEADAAN NARAPIDANA DI LP-LP YANG DITELITI MENURUT PEMELUKAN AGAMA SEPTEMBER - OKTOBER 1994}

\begin{tabular}{|c|c|c|c|c|c|}
\hline No. & & NAMA & $\begin{array}{l}\text { ISLAM } \\
(\%)\end{array}$ & $\begin{array}{l}\text { NON ISLAM } \\
\left(\frac{\circ}{\circ}\right)\end{array}$ & JUMLAH \\
\hline 1 & LP & Ujungpandang & $\begin{array}{c}611 \\
(95,92)\end{array}$ & $\begin{array}{c}26 \\
(04,08)\end{array}$ & 637 \\
\hline 2 & LP & Maros & $\begin{array}{r}94 \\
(100)\end{array}$ & - & 94 \\
\hline 3 & LP & Bulukumba & $\begin{array}{c}242 \\
(100)\end{array}$ & - & 242 \\
\hline 4 & LP & Watampone & $\begin{array}{c}153 \\
(100)\end{array}$ & - & 153 \\
\hline 5 & LP & Polewali & $\begin{array}{c}89 \\
(86,41)\end{array}$ & $\begin{array}{c}14 \\
(13,59)\end{array}$ & 103 \\
\hline \multirow[t]{2}{*}{6} & LP & Palopo & $\begin{array}{c}75 \\
(70,1)\end{array}$ & $\begin{array}{c}32 \\
(29,9)\end{array}$ & 107 \\
\hline & & JUMLAH & $\begin{array}{c}1.264 \\
(94,61)\end{array}$ & $\begin{array}{c}72 \\
(05,39)\end{array}$ & 1.336 \\
\hline
\end{tabular}

Catatan : Data tabel di atas hanya data narapidana tidak termasuk tahanan.

2) Data tentang program kegiatan pembinaan keagamaan bagi narapidana non muslim terprogramkan dengan jelas di LP Palopo.

3) Sistem diskusi dalam pelajaran agama Islam, dipraktekkan secara baik di LP Bulukumba.

4) Informasi yang diperoleh dari petugas LP bersangkutan bahwa sistem diskusi dalam pelajaran agama Islam disenangi narapidana peserta diskusi.
5) Mengadakan perlombaan menjadi semacam MTQ di tiap-tiap LP yang diteliti, juga dimaksudkan sebagai seleksi calon peserta yang akan dikirim mengikuti MTQ antar narapidana se Sulawesi Selatan yang diselenggarakan setiap tahun (pada bulan Ramadhan) di LP Kelas I Ujungpandang.

6) Keikutsertaan instansi Departemen Agama di LP-LP se Sulawesi Selatan dalam kegiatan pembinaan kehidupan beragama narapidana, didasarkan pada Piagam Kerjasama antara (Kepala) Kantor Wilayah Departemen Kehakiman Sulawesi Selatan dengan (Rektor)) Institut Agama Islam Negeri Alaudin 
POLA PEMBINAAN KEAGAMAAN NARAPIDANA

DI LEMBAGA PEMASYARAKATAN SULAWESI SELATAN

Ujungpandang dan (Kepala) Kantor Wilayah Departemen Agama Propinsi Sulawesi Selatan, masing-masing bernomor :W-15-OO.0301-6300; A-I/HM.01/2003/1987; 50Tahun 1987, tertanggal 31 Oktober 1987. Piagama Kerjasama tersebut ditandatangai oleh masing-masing : Kepala Kanwil Departemen Kehakiman Propinsi Sulawesi Selatan Drs.R. Soegondo; Rektor IAIN Alauddin Ujungpandang Dra. A. Rasdiyanah; dan Kepala Kanwil Departemen Agama Propinsi Sulawesi Selatan Drs. H. Abdurrahman K.

\section{DAFTAR KEPUSTAKAAN}

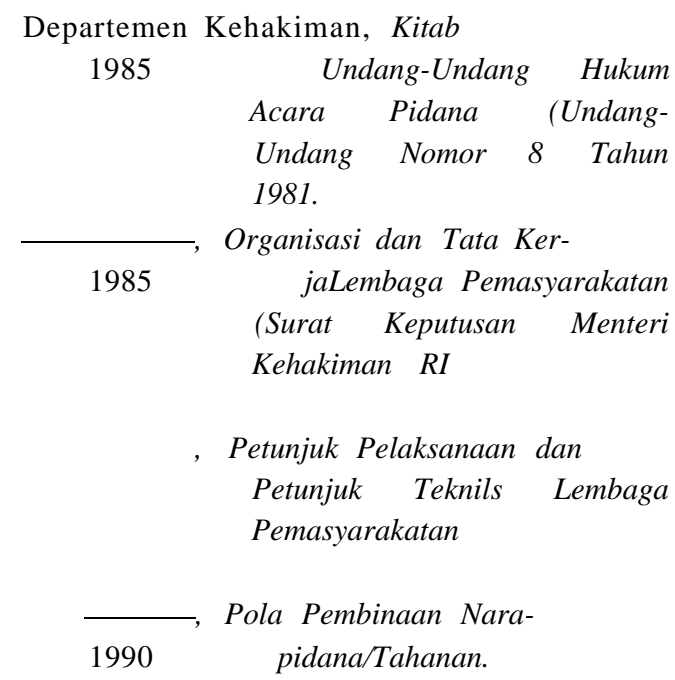

Direktorat Penyuluhan Hukum Departemen Kehakiman RI, UndangUndang Hukum Acara Pidana dan Peraturan Pelaksanaannya.

Direktorat Jenderal Pemasyarakatan Departemen Kehakiman RI, Majalah Pemasyarakatan Nomor 1 Tahun 1993
Krippenderff, Klaus (Terjemahan),i4na/isw, Pengantar Teori dan Metodologi, Jakarta, Rajawali Pers.

Koentjaraningrat dan K. Aspek

1985 Manusia dalam Penelitian Masyarakat. Jakarta Gramedia.

Vredenbregt, J. Metode dan 1981 Teknik Penelitian Masyarakat, Jakarta, Gramedia. 